\title{
ОСНОВНЫЕ ФАКТОРЫ МИГРАЦИИ И СТРУКТУРА МИГРАНТОВ В ПОСТКОММУНИСТИЧЕСКОЙ ГРУЗИИ
}

\author{
АВТАНДИЛ СУЛАБЕРИДЗЕ, ИОСИФ АРЧВАДЗЕ, ВЛАДИМИР СУЛАБЕРИДЗЕ
}

\begin{abstract}
Неуклонный рост эмиграции в посткоммунистический период (1992-2014 г2.) в условиях нулевого естественного прироста населения оказал значительное влияние на социально-демографическое и экономическое развитие страны. Начиная с 1992 г., численность населения Грузии сократилась почти на 1/3 и к 2018 г. составила 3,7 млн человек.

Из многих факторов эмиграчии из Грузии определяющими были три: первый - этническая миграция - возвращение после распада Советского Союза на свою историческую родину сотен тысяч представителей других наџиональностей, живших в Грузии, в результате чего доля грузин в общей численности населения в $1989-2017$ г2. выросла с 69,7 до 86,8\% (в том числе в пределах подконтрольной в настоящее время Тбилиси территории - с 73,2\% до 86,8\%); второй - эмиграция большой массы беженцев с потерянных территорий (Абхазская АР и Юго-Осетинская АО); третий - социально-экономический коллапс, переживаемый Грузией в тот период.
\end{abstract}

Высокий уровень эмиграции вызвал заметную деформацию половозрастной структурь населения. Приблизительно на 8 лет увеличился медианный возраст населения. Из множества аспектов мигращии следует обратить особое внимание на рост женской (хотя преобладание мужчин среди эмигрантов сохраняется) и студенческой (молодежной) эмиграџии заграницу. В последние годы систематически растет образовательный цеенз эмигрантов, из-за чего все более насущной и острой становится проблема «утечки мозгов».

Важным носителем импульса потенциальной эмиграции является почти половина (48\%) студенческой молодежи, которая в ближайшие 5 лет хотела бы выехать заграницу для получения достойного образования и желаемой работы.

Ключевые слова: миграция, мотивация, трудовые мигранты, нелегальная миграция.

\section{ВВЕДЕНИЕ}

После распада СССР в общей численности и структуре населения Грузии произошли заметные изменения. Вялотекущая миграция из республики и отрицательное миграционное сальдо отмечались в Грузии уже с 1957 г., хотя до этого наблюдалась противоположная тенденция: массовая миграция представителей других национальностей в Грузию. Если армяне и азербайджанцы проживали в Грузии испокон века, то процесс индустриализации, строительство крупных промышленных объектов и тому подобное способствовали абсолютному и относительному росту численности представителей славянских национальностей - русских и украинцев.

АвТАНДИЛ СУЛАБЕРИДЗЕ (sulaberidzeavtandil@gmail.com), ИНСТИТУТ ДЕМОГРАФИИ И СОЦИОЛОГИИ ГОСУДАРСТВЕННОГО УНИВЕРСИТЕТА ИЛЬИ, ГРУЗИЯ.

ИОСИФ АРчвАдЗЕ (daswreba@yahoo.com), ИНСТИТУТ ДЕМОГРАФИИ И СОЦИОЛОГИИ ГОСУДАРСТВЕНОГО УНИВЕРСИТЕТА ИЛЬИ, ГРУЗИЯ.

ВЛАДИМИР СУЛАБЕРИДЗЕ (lado.posta@gmail.com), ИНСТИТУТ ДЕМОГРАФИИ И СОЦИОЛОГИИ ГОСУДАРСТВЕННОГО УНИВЕРСИТЕТА ИЛЬИ, ГРУЗИЯ.

СТАТЬЯ ПОСТУПИЛА В РЕДАКЦИЮ В МАРТЕ2О19 Г. 
Но уже с середины XX столетия отрицательное миграционное сальдо в среднегодовом исчислении составило 20-25 тыс. человек. А после обретения государственной независимости миграция из Грузии в другие страны, ранее входившие в состав СССР, интенсифицировалась, продолжается по сегодняшний день и к настоящему времени со всеми этими странами сохраняется отрицательное миграционное сальдо. Несмотря на то, что уже с середины 1990-х годов экономическое развитие Грузии приобрело более или менее устойчивый характер, а в отдельные годы (1996, 1997, 2003, 2007 экономический рост повышался до 10-12\%, это не уменьшило отрицательную чистую миграцию. Низкий естественный прирост с начала 1990-х годов уже не компенсирует высокий отрицательный баланс внешней миграции, что ведет к сокращению общей численности населения страны.

По сравнению со среднегодовым уровнем 1980-х годов, естественный прирост (50 тыс. человек) в 1990-х годах уменьшился в среднем на 45 тыс. человек, в то время как уже в первые годы и до самой середины 1990-х ежегодное отрицательное миграционное сальдо превысило 100 тыс. человек. Несмотря на уменьшение отрицательного сальдо миграции с 2000г. (в среднем за период 2000-2017 гг. - 23 тыс. человек), падение естественного прироста до грани депопуляции остается основным фактором, влияющим на уменьшение численности населения Грузии.

Все это не могло не повлиять на структуру населения, в том числе и по этническому признаку. Грузию, до того времени славившуюся относительно низкой эмиграционной активностью, из-за ухудшения экономического положения стали покидать многие десятки тысяч семей как коренной национальности, так и представителей этнических меньшинств. Ситуация усугублялась и тем, что, в результате этнических конфликтов в двух регионах Грузии (Абхазская АР, Юго-Осетинская АО), из них из-за вынужденной, насильственной миграции ${ }^{1}$ практически в форме этнической чистки было почти полностью выдавлено грузинское население. По экспертным оценкам, в настоящее время до 2/3 грузин, покинувших Абхазию и Южную Осетию, проживает в Грузии, остальные находятся в разных странах мира.

Все это коренным образом изменило структуру населения Грузии.

Эмиграция жителей Грузии, решившихся покинуть страну начиная с 1990-х годов, имела следующие основные причины:

- $\quad$ ля этнических грузин: в основном, тяжелая экономическая ситуация на родине и потеря крова в Абхазской АР и Юго-Осетинской АО для нескольких сотен тысяч жителей этих регионов;

\footnotetext{
${ }^{1}$ Миграция, по своей природе, - процесс, который отражает стремление индивида удовлетворить определенные потребности, в связи с чем добровольно, без всякого насилия и принуждения меняет временное или постоянное место жительства (например, трудовая миграция, миграция для получения образования, с целью улучшения материального положения и др.). Вынужденная, насильственная миграция происходит по политическим, военным и другим экстраординарным причинам. В результате нее люди массово становятся беженцами, остаются практически без всяких средств к существованию и, в отличие от обычных мигрантов, без политических решений, по своей воле не могут вернуться к своему очагу (Sulaberidze 2008).
} 
- для представителей большинства других этнических групп: наряду с тяжелой экономической ситуацией, знание русского языка как языка межнационального общения при незнании (или плохом знании) государственного языка Грузии. Указанный фактор был одним из акселераторов этнической миграции (репатриации, возвращения) на свою историческую родину сотен тысяч этнических русских, украинцев, греков, евреев и др. Поэтому интенсивность эмиграции среди других этнических групп в 1990-е годы была существенно (почти в два раза) выше, чем среди грузин.

Миграционные процессы можно условно разделить на два этапа:

Первый этап - с начала 1990-х до середины 2000-х годов, когда поток эмиграции из страны практически не сопровождался сколько-нибудь заметным потоком в противоположном направлении. Обвал экономики, падение производства, массовое сокращение рабочих мест, тотальное обнищание населения делали крайне непривлекательными и некомфортными условия быта и жизни в стране. Соответственно, люди однозначно стремились выехать из Грузии в поисках лучшей участи. Только за 19912000 гг. из Грузии выехал почти каждый пятый житель страны. На фоне столь мощной эмигрантской волны иммиграция в Грузию, хотя она и имела место, казалась маленькой, еле заметной струйкой.

Второй этап -период с середины 2000-х годов по настоящий день. За это время экономика в основном стабилизировалась, благодаря чему поток эмиграции из Грузии по экономическим причинам пошел на некоторый спад (при одновременном резком увеличении выезда из Грузии с целью получения образования за рубежом), и одновременно увеличился приток иммигрантов из других стран для постоянного проживания и ведения бизнеса в Грузии.

\section{ПРОБЛЕМЫ МЕТОДОЛОГИИ УЧЕТА МИГРАЦИИ}

В настоящей статье использованы официальные данные грузинской статистики (Грузстат) и Министерства внутренних дел, а также материалы социологических исследований, проведенных в Институте демографии и социологии государственного университета Илъи с целью изучения проблем миграции; результаты исследований международных организаций, грузинских и зарубежных ученых; материалы ООН, МОМ и др.

Тенденции современной грузинской миграции изучали многие исследователи (Т. Гугушвили, Г. Цуладзе, М. Тухашвили, М. Шелия и др.). В ходе исследований все они столкнулись с проблемами текущего учета миграции, а также некорректными результатами переписи населения. В отличие от постсоветского периода, упомянутая информация в советский период более или менее полно отражала миграцию (Денисенко, Чудиновских 2018: 182-205; Tsuladze, Maglaperidze, Vadachkoria 2005; Tsuladze, Sulaberidze 2016; Archvadze 2013).

Неверный учет миграции в основном является следствием неправильной методологии. В частности, до 2012 г. Департамент охраны границы Грузии регистрировал лишь количество посещений визитеров, но не вел учет продолжительности визитов и 
других параметров, которые позволили бы Грузстату дать полную объективную картину масштабов международной миграции. С 2012 г., используется новая методология для определения статуса мигрантов, соответствующая международным стандартам, что значительно улучшило качество учета внешней миграции.

Критическое отношение к оценке численности населения во многом обусловлено «переписным листом эмигрантов», который практически не сработал или плохо сработал во время обеих Всеобщих переписей населения Грузии (2002 и 2014 гг.). Если судить по данным переписи населения 2014 г., то, по сравнению с переписью 2002 г., численность эмигрантов из Грузии сократилась на 22,1\% (с 113,7 тыс. до 88,5 тыс.). В то же время официальные данные МВД показывают совершенно иную картину. В отдельные годы реальные масштабы внешней миграции на порядок превышали соответствующие официальные данные Статведомства Грузии: в 2005 г. - в 14 раз, в 2009 г. - в 16 раз, а в 2010 и 2011 г. - в 18 раз (Sulaberidze 2017: 74).

Несмотря на различие данных по вышеприведенным двум источникам, неполный учет миграции при переписях населения, такой учет не следует полностью игнорировать, ибо он все же дает определенное представление о качественных характеристиках внешней миграции и может быть использован для объяснения миграционного поведения эмигрантов и иммигрантов, поскольку в специальном опроснике (форма 3, «Опросник об эмиграции») рядом с традиционными демографическими показателями имелись вопросы: дата выезда из страны, предполагаемая страна проживания, причина эмиграции, вид деятельности в настоящее время, экономические связи с оставшимися в Грузии членами семьи.

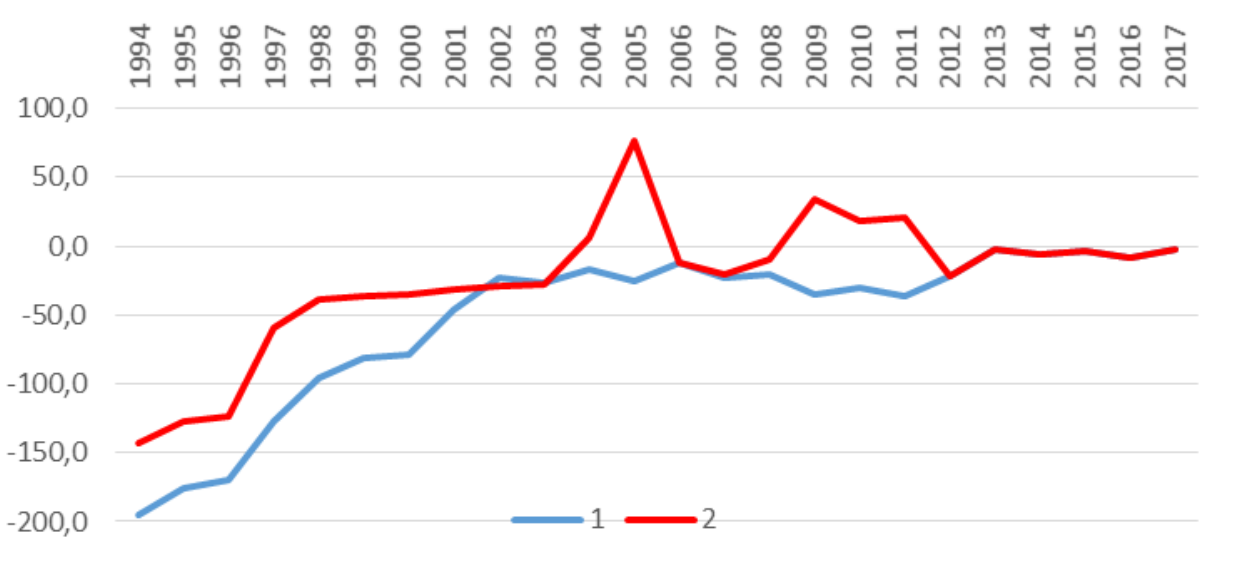

\section{Рисунок 1. Динамика чистой миграции населения Грузии, 1994-2014}

Источник: Материалы Грузстата.

Примечание: 1- оценка чистой миграции населения; 2 - официальные данные о чистой миграции.

В результате использования вышеупомянутой неправильной методологии, по расчетам Грузстата ${ }^{2}$, внешняя отрицательная чистая миграция в период между двумя переписями населения 1989-2002 гг. составила для Грузии почти 930 тыс. человек²,

\footnotetext{
${ }^{2}$ С декабря 2009 г. Государственный департамент Грузии по статистике переименован в Грузстат.

${ }^{3}$ Geostat. Statistical collection (2003). Population census 2002 results. Vol. 3(2), 67. URL: http://census.ge/files/2002/geo/III-2\%20tom.pdf (дата обращения: 25.05.2019). 
а в 2002-2014 гг. положительная чистая миграция составила 24 тыс. человек. Альтернативная оценка, произведенная Г. Цуладзе (Tsuladze 2016: 18), указывает на наличие отрицательного сальдо за период 2002-2014 гг. в размере 320 тыс. человек.

По официальным данным, отрицательная чистая миграция в 1990-2000 гг. составляла 135,2 тыс. человек, что в 6,5 раза меньше соответствующих данных, рассчитанных профессором Цуладзе с соавторами (Tsuladze, Maglaperodze, Vadachkoria 2002: 113). Начиная с 2012 г., с переходом Грузстата к новой методологии, учет миграции улучшен. Следовательно, с 2013 г. оба показателя (официальный и оценочный) чистой миграции практически совпадают друг с другом, о чем наглядно свидетельствует рисунок 1.

\section{ЭКОНОМИЧЕСКИЙ ФАКТОР МИГРАЦИИ}

Специфической чертой и главной мотивацией миграции населения Грузии являются структурная безработица и дефицит рабочих мест при одновременном более или менее удовлетворительном размере средней оплаты труда наемных работников. Уровень безработицы в Грузии составляет 13,9\%, однако половина занятых - самозанятые (в основном, в сельском хозяйстве), чей труд наименее продуктивный, а доходы наиболее низкие. По сравнению с началом 1990-х годов, в 2018 г. население страны сократилось на 1730 тыс. человек, а число наемных работников - более чем на 1400 тыс. В настоящее время доля наемных работников в общей численности населения почти в два раза ниже, чем в начале 1990 -х годов (22,1\% и 41,0\% соответственно). За тот же период численность занятых по найму на каждые 100 домашних хозяйств сократилась почти вдвое - с 157 до 79, что повлияло на общее благосостояние семей и многих вынудило искать источник дохода в трудовой эмиграции. Это нашло соответствующее отражение и в макроэкономических показателях. Так, зарплатоемкость ВВП Грузии составляет лишь $24 \%$, в то время как в странах ЕС - почти 40\%. Именно низкая емкость рынка труда в Грузии определяет трудовую эмиграцию ее граждан.

Эмиграция обусловила значительное сокращение численности населения, особенно сельского. Существующая до 1992 г. внутренняя миграция по направлению село-районныий центр - город в основном определяла рост населения городов. В последующий период вследствие прямой миграции сельского населения заграницу поток мигрантов село - город уменьшился (Tukhashvili 2018: 175-182).

После распада Советского Союза все регионы Грузии подверглись сокращению численности населения. Столице Грузии Тбилиси едва удалось сохранить численность населения на уровне начала 1990-х годов за счет массового наплыва насильственно перемещенных лиц (беженцев) из Абхазии и Южной Осетии, многих вынужденных мигрантов из регионов (преимущественно из сельской местности), а также за счет изменения административно-географических границ и включения несколько десятков населенных пунктов в свой состав.

Уменьшению численности населения Грузии в целом также способствовало замещение сезонной миграции, существовавшей в советское время, нелегальной 
долгосрочной эмиграцией за рубеж. В результате интенсивной миграции из деревни, по данным Всеобщей переписи населения Грузии 2014 г., по сравнению с переписью 2002 г. в 1,5 раза возросло число опустевших деревень (223), что составило 6\% от числа сельских поселений (Tsuladze, Sulaberidze 2016: 34-35).

На миграцию, кроме экономических, повлияли и социально-демографические факторы: получение образования, беженство, желание улучшения быта и др. Эти факторы в значительной мере обусловливают позитивное отношение к высокоразвитым странам приема мигрантов и негативное - к стране-донору. Соответственно, чем больше разница между позитивными и негативными факторами, тем выше ожидаемая в другие страны миграция и вероятность остаться там (Вишневский 2015). Ввиду этого, характеризуя миграционные процессы Грузии, половозрастную, социальную и этническую структуру мигрантов, их образовательный ценз, мы получаем практически полную картину экономического положения страны-донора мигрантов, и в этом отношении Грузия не исключение.

\section{ЭТНИЧЕСКАЯ СОСТАВЛЯЮЩАЯ МИГРАЦИИ}

В постсоветский период интенсивность внешней миграции представителей различных национальностей, проживающих в Грузии, существенно различалась. По данным двух последних переписей населения, за период 2002-2014 гг. доля грузин в национальной структуре эмигрантов выросла с 60,9\% до 83,8\%, особенно большим был ее рост среди женщин (с 56,3\% до 87,2\%), при одновременном сокращении доли представителей других национальностей: азербайджанцев - до 5,9\%, армян - до 5,0\%, русских - до 0,9\%, осетин до $0,7 \%$, греков - до 0,4\%. Основной причиной эмиграции жителей Грузии вышеназванных этнических групп были тяжелые экономические условия 1990-х годов. Однако ввиду того, что значительная их часть эмигрировала на свою историческую родину, их отъезд приобрел окраску «этнической миграции».

В период между переписями населения 1989-2002 гг. высокой была интенсивность внешней чистой миграции белорусов, евреев и украинцев. Среди представителей других этнических групп с относительно высокой интенсивностью внешней миграции, следует назвать осетин, греков и русских. Более низкая интенсивность была характерна для азербайджанцев и армян. Соответствующий показатель для грузин был самым низким. Дифференцированная по национальности эмиграция, по существу, обусловила в основном рост доли грузин в общей численности населения Грузии с 69,7\% (1989 г.) до 86,8\% (2014 г.).

Доля грузинского населения в Грузии в предконфликтный период составляла $70,13 \%$, в Абхазской АР 45,68\%, в Юго-Осетинской АО - 28,97\% (все оценки - по итогам переписи 1989 г.). В двух автономных образованиях Грузии проживало 11,55\% населения, в том числе 7,09\% этнических грузин Грузинской ССР. Без учета всего населения этих двух автономий доля грузинского населения в общей численности населения, проживающего на остальной территории Грузии (т.е. территории, которая в настоящее время контролируется государством), составляла 73,7\%. Если проецировать нынешнюю подконтрольную Грузии 
территорию на 1989 г., то получится, что доля грузинского населения за 1989-2014 гг. возросла лишь на 13,1 пункта (с 73,7 до 86,8\%). Для сравнения: за тот же период доля казахского населения в Казахстане возросла на 26,8 пункта (с 39,7 до 67,5\%) коренного населения Киргизии возросла на 20,6 пункта (с 52,4 до 73,0\%) ${ }^{5}$, а доля коренного населения Узбекистана - на 11,5 пункта (с 71,4 до 82,9\%).

Рост доли коренного населения и степени этнической гомогенности являются характерной чертой, а не исключением, для вновь образованных государств на всем постсоветском пространстве, обусловленной не в последнюю очередь более высокой интенсивностью эмиграции некоренного населения по сравнению с эмиграцией представителей титульной нации страны.

\section{ПОЛОВОЗРАСТНАЯ СТРУКТУРА МИГРАНТОВ}

Если исключить факторы, связанные с форс-мажором (войны, стихийные бедствия), то общей закономерностью миграции является миграция для улучшения своего экономического положения. В силу этого в авангарде потока мигрантов во всем мире стоят люди в трудоспособном возрасте (с членами своих семей или без них). Их доля среди мигрантов существенно выше доли лиц соответствующей возрастной группы в общей численности населения. При общем сокращении абсолютного числа эмигрантов из Грузии доля соответствующей возрастной группы не только не сократилась, но даже несколько выросла, о чем красноречиво повествует приведенная ниже таблица 1, составленная по данным Всеобщих переписей населения Грузии 2002-2014 гг.

Таблица 1. Половозрастная структура грузинских мигрантов по укрупненным возрастным группам, 2002-2014, \%

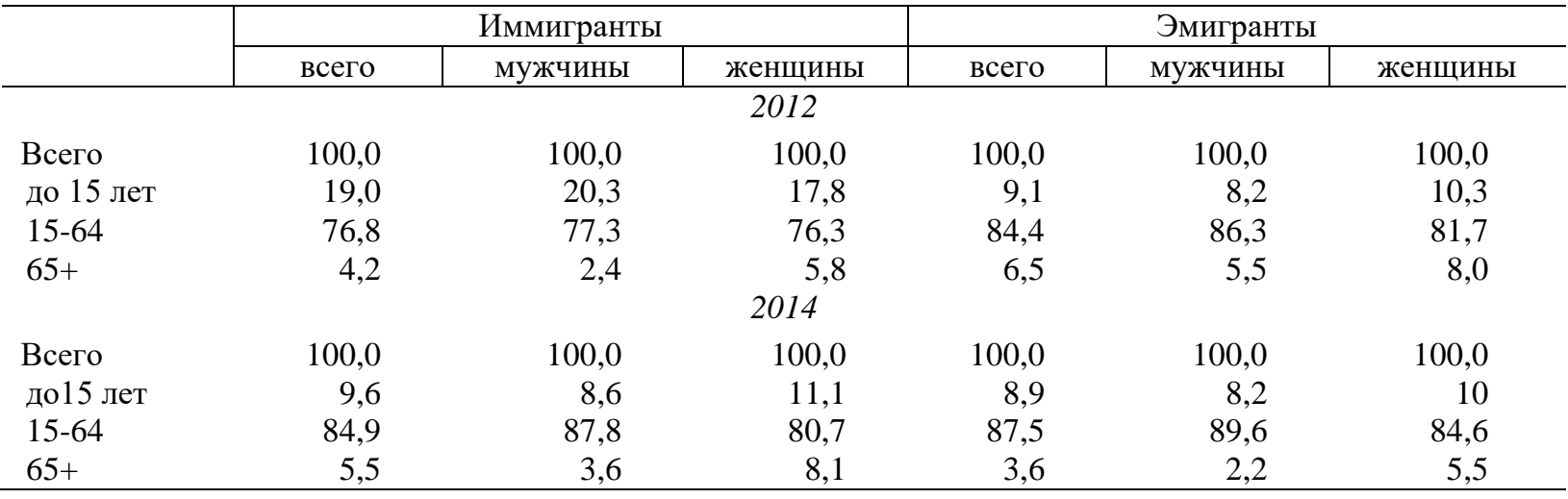

Источник: Материалы Всеобщих переписей населения Грузии 2002 и 2014 г.

Из общего контингента эмигрантов 85\% - лица в возрасте 20-50 лет. Получается явная асимметрия между структурой населения и контингентом эмигрантов: в возрастной группе 15-64 года при ее доле в населении 66,5\% доля в численности эмигрантов на

\footnotetext{
${ }^{4}$ URL: www.stat.gov.kz (дата обращения: 25.05.2019).

${ }^{5}$ URL: www.stat.kg (дата обращения: 25.05.2019).

${ }^{6}$ URL: www.stat.uz (дата обращения: 25.05.2019).
} 
21 процентных пункта выше - 87,5\%, а в возрастной группе 20-50 лет соответствующие показатели составляют 40,7 и 72,2\% (данные 2014 г.).

С тем, что в общей численности грузинских эмигрантов большинство составляют лица трудоспособного возраста от 15 до 64 лет, в значительной степени связан резкий спад рождаемости в Грузии при одновременном росте числа рождений в семьях мигрантов из Грузии. По экспертным оценкам ежегодно в таких семьях за пределами Грузии рождалось не менее 7-8 тыс. детей, в целом же за весь период с 1992 г. - не менее 200 тыс. детей

Одним из весомых негативных последствий миграционных процессов для постсоветской Грузии стало быстрое старение населения. Страну в основном покидали и покидают люди в возрасте, наиболее плодотворном с экономической и демографической точек зрения. Доля лиц 20-50 лет среди мигрантов существенно превышает, как было сказано выше, долю соответствующей возрастной когорты в общей численности населения. По этой причине, а также ввиду тяжелых экономических условий в 1990-х годах у населения, имеющего более или менее высокий стандарт быта и потребления, произошел резкий спад рождаемости. Поэтому после распада СССР медианный возраст населения Грузии увеличился почти на 7 лет (с 31 до 38 лет), а соотношение числа детей до 15 лет к числу лиц пожилого возраста и снизилось до критически низкого уровня и в настоящее время не намного превышает 100\%-й уровень.

Данные текущей статистики последних лет показывают, что отмечаются определенные изменения в соотношении мигрантов по полу. Так, в течение 2002-2012 гг. среди мужчин число эмигрантов превышало число иммигрантов, в течение 2013 и 2015 г., а в 2017 г. число иммигрантов превысило число эмигрантов. Большинство иммигрантов, граждане Грузии, что свидетельствует об их растущем желании вернуться домой. Сокращение масштабов эмиграции и рост иммиграционного потока связаны с ростом и стабилизацией экономики страны, крупными инвестициями из-за рубежа и повышением уровня жизни в стране.

До 2013 г. среди мужчин число эмигрантов было выше числа иммигрантов, но в течение 2013 и 2015 г. показатели сравнялись. В 2017 г. иммигрантов стало больше чем эмигрантов.

Среди женщин, в отличие от мужчин, число эмигрантов по-прежнему выше числа иммигрантов. Однако в возрасте старше 65 лет (по данным за 2017 г.) наблюдается ощутимое преобладание числа женщин (5,3\%) по сравнению с мужчинами $(2,2 \%)$. Это дает основания полагать, что желающих вернуться на родину будет больше. К 2017 г. среди иммигрантов старше 65 лет доля женщин (7,3\%) была существенно выше, чем среди мужчин $(3,1 \%)$.

\footnotetext{
${ }^{7}$ URL: http://diaspora.ge (дата обращения: 25.05.2019). 


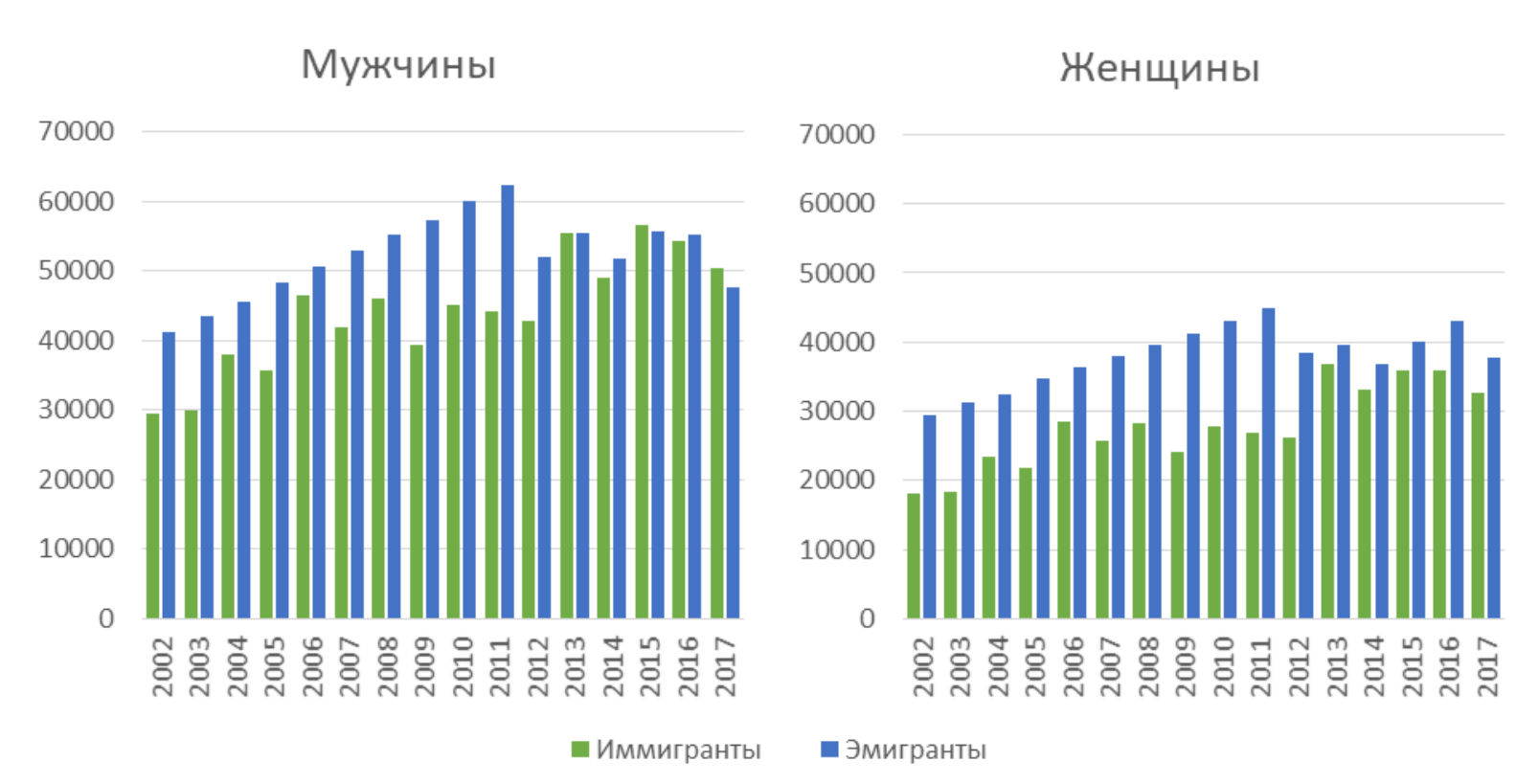

Рисунок 2. Иммигранты и эмигранты по полу в Грузии, 2002-2017

Источник: Материаль Грузстата. URL: www.geostat.ge (дата обращения: 18.05.2019).

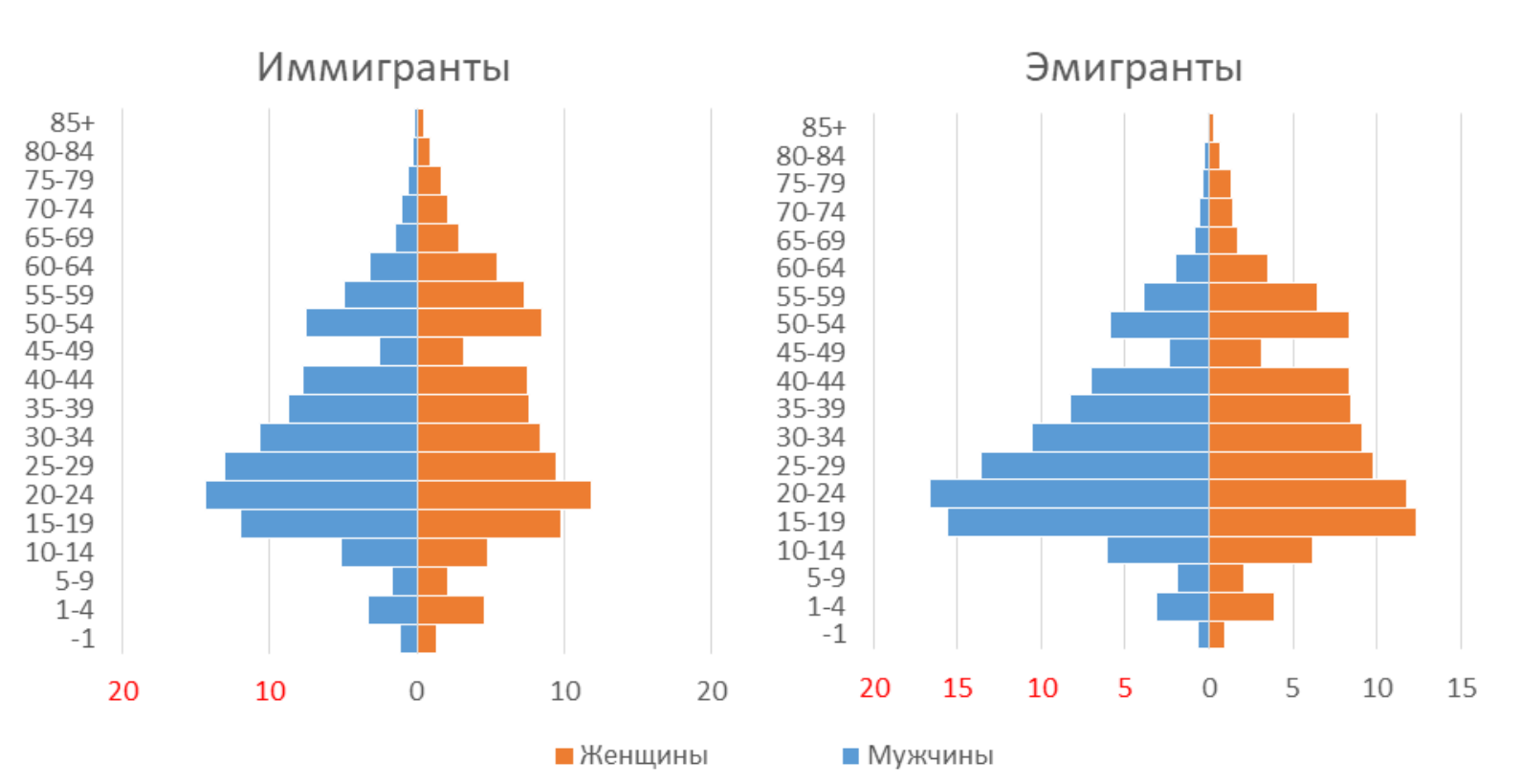

Рисунок 3. Половозрастная пирамида мигрантов в 2014 г., (по данным Всеобщей переписи населения Грузии; кумулятивные данные за 1992-2014 гг.), \%

Источник: Материаль Всеобщей переписи населения 20142.

Сравнение данных двух последних переписей населения Грузии (2002 и 2014) показало, что значительная часть эмигрантов старших возрастных групп преодолела трудности в стране приема (нашли работу, учатся, урегулировали жилищные и бытовые проблемы, получили статус беженца или гражданство и др.) и не намеревается в обозримом будущем возвращаться на родину. Одновременно в этой возрастной группе имели место сокращение потенциала желающих выехать за рубеж и увеличение иммиграции по возрастным причинам (нельзя исключать и другие причины: болезни, ностальгию по 
членам семьи и др.). Все это привело к сокращению доли старшей возрастной группы среди мигрантов.

В результате миграционного оборота 1992-2014 гг. к 2014 г. сформировалась аккумулированная структура мигрантов Грузии, представленная на рисунке 3.

\section{ОБРАЗОВАТЕЛЬНЫЙ УРОВЕНЬ МИГРАНТОВ}

Для того, чтобы закрепиться на новом месте, в другой стране, если миграция не связана с гуманитарными проблемами, необходимы определенные знания, профессиональный и предпринимательский опыт, что имеет наиболее высокую корреляцию с образовательным уровнем населения. Конкуренция за «место под солнцем» идет и среди мигрантов, что априори требует определенного уровня общего и профессионального образования. При сокращении общего числа эмигрантов из Грузии по сравнению с 1990-ми годами, очевиден рост их образовательного уровня. В 2014 г. по сравнению с 2002 г. выросла доля эмигрантов с высшим и средне-профессиональным образованием (таблица 2).

Таблица 2. Распределение эмигрантов Грузии по достигнутому уровню образования в 2002 и 2014 г., \% (общее число эмигрантов - 100\%)

\begin{tabular}{l|c|c|c|c}
\hline Год & $\begin{array}{c}\text { Высшее } \\
\text { образование }\end{array}$ & $\begin{array}{c}\text { Профессиональное } \\
\text { образование }\end{array}$ & $\begin{array}{c}\text { Среднее } \\
\text { образование }\end{array}$ & Другое \\
\hline 2002 & 25,3 & 15,1 & 49,1 & 10,5 \\
2014 & 34,3 & 18,4 & 43,0 & 4,3 \\
\hline
\end{tabular}

В межпереписной период, как свидетельствует таблица 2, доля мигрантов с высшим образованием увеличилась почти в 1,4 раза, а эмигрантов со средним образованием сократилась на 6,1 пункта (с 49,1 до 43,0\%).

При этом наблюдается определенное различие в уровне образования по странам, куда направляются мигранты из Грузии. Доля мигрантов с высшим образованием выше в Италии, Германии, США, Испании и Франции, а ниже в России, Греции и Турции (таблица 3).

Таблица 3. Распределение трудовых мигрантов из Грузии с разным уровнем образования по странам (по данным переписи населения 2014 г.)

\begin{tabular}{|c|c|c|c|c|c|c|c|c|c|c|}
\hline Образование & Всего & 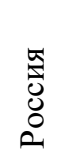 & 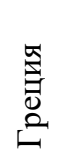 & 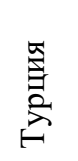 & 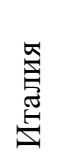 & 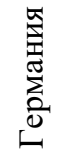 & 寻 & 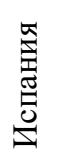 & 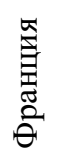 & 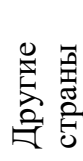 \\
\hline Всего & 100,0 & 21,6 & 16,2 & 11,5 & 11,1 & 7,0 & 5,6 & 4,1 & 3,5 & 32,5 \\
\hline Высшее & 100,0 & 17,7 & 12,1 & 7,1 & 12,3 & 11,2 & 10,1 & 4,6 & 4,0 & 36,8 \\
\hline Среднее профессиональное & 100,0 & 19,7 & 21,6 & 13,2 & 14,7 & 4,9 & 3,7 & 4,4 & 2,4 & 26,5 \\
\hline Среднее & 100,0 & 25,1 & 17,9 & 14,7 & 9,1 & 4,7 & 2,7 & 3,4 & 3,3 & 30,6 \\
\hline
\end{tabular}

Вышеприведенные данные свидетельствуют, что ментальная и территориальная близость, общность культуры и вероисповедания благоприятствуют миграции лиц даже с относительно низким образовательным цензом, в то время как географическая отдаленность и языковые барьеры предъявляют более высокие профессиональные и 
языковые требования к потенциальным мигрантам. Так, в трех странах (США, Германии, Италии), на которые приходится менее четверти всех грузинских трудовых мигрантов $(23,7 \%)$, сосредоточено более $1 / 3$ мигрантов с высшим образованием $(33,6 \%)$. Показательный пример - США: 5,6\% всех мигрантов из Грузии, но 10,1\% мигрантов с высшим образованием.

При сохранении экономической причины в качестве главенствующего фактора эмиграции (к 2014 г. 70,8\% эмигрантов работали), растет число тех эмигрантов, которые выехали за границу с целью обучения (с 6,6\%в 2002 г. до 11,0\% в 2014 г.) или воссоединения семей, т.е. наряду с экономической составляющей в мотивации эмиграции постепенно растут социально-культурные и гуманитарные компоненты.

\section{ГЕОГРАФИЯ МИГРАЦИИ}

Основной поток эмиграции в начале 1990-х годов направлялся в Российскую Федерацию (в отдельные годы - до 4/5 всех выезжающих за пределы Грузии). Со временем миграционный поток и его география существенно диверсифицировалась. Происходит активное перераспределение потоков и общего числа эмигрантов из Грузии по странам мира. Так, еще в 2002 г., по данным переписи населения, в России находился 64,1\% эмигрантов из Грузии, а к 2014 г. их доля сократилась в 3 раза (до 21,6\%). При этом среди мужчин произошло двукратное (с 69,4 до 34,0\%), а среди женщин - пятикратное (с 56,7 до $11,5 \%$ ) сокращение. Свою роль в этом сыграли экономические санкции западных стран по отношению к России, падение курса рубля по отношению к доллару, а также введение Россией визового режима для граждан Грузии и политическая напряженность между РФ и Грузией.

Одновременно при уменьшении эмиграции в Россию сильно «подтянулись» Греция $(16,2 \%$ от общего числа эмигрантов из Грузии), Турция и Италия $(11,5 \%)$, Германия $(7,1 \%)$, США (5,7\%), Испания $(4,1 \%)$, Франция $(3,7 \%)$ и др. На первые три страны приходится почти половина всех мигрантов из Грузии. При этом наблюдается своеобразная «миграционная гендерная сегрегация» по странам. Мужчины-мигранты все еще предпочитают Россию, женщины же - Грецию и Италию. По данным последней переписи населения Грузии (2014 г.), доля эмигрантов-мужчин в Россию превышала соответствующий показатель среди женщин в 3,1 раза (соответственно 34,3 и 11,1\%), в то время как по Италии и Греции, наоборот, наблюдалась прямо противоположная картина. Доля мигрантов-женщин в Италии в общей их численности превысила соответствующий показатель среди мужчин в 5,1 раза $(17,4$ и 3,4\%), а в Греции - в 4,2 раза (5,9 и 24,6\%).

По данным последней Всеобщей переписи населения, в этнической структуре эмигрантов доля грузин составляет $83,9 \%$, что больше показателя предыдущей переписи (2002 г.) на 23 пункта. Доля азербайджанцев составляет 5,9\%, а армян - 5,0\%, что примерно соответствует доле жителей этих национальностей в общей численности населения Грузии (азербайджанцы - 6,3\%, армяне - 4,5\%). 


\section{ПРИРОДА, ГЕОГРАФИЯ И ОСНОВНЫЕ ПРИЧИНЫ ЖЕНСКОЙ ЭМИГРАЦИИ из Грузии}

Традиционный стереотип мышления (дескать, мужья не должны позволять женам уезжать на долгое время за рубеж), быстро улетучился, ибо экономическая потребность оказалась гораздо более серьезным доводом, чем старые взгляды и предрассудки. В настоящее время многие десятки тысяч женщин зарабатывают деньги для содержания своих домочадцев, оставшихся на родине. За счет высланных эмигрантами на родину денег покрываются налоги, оплачиваются коммунальные платежи и банковские ссуды, учатся дети, лечатся родители и родственники. Значительная часть женщин находится в качестве трудовых мигрантов в странах, где уровень жизни и средняя зарплата значительно выше, чем в Грузии (США, Италия, Германия, Греция, Турция и др.), в связи с чем даже их простой (но физический, монотонный, длительный и утомительный) труд оплачивается, по грузинским меркам, относительно высоко. Несмотря на то, что низкоквалифицированный труд вызывает дисквалификацию, эмигранты-женщины вынуждены соглашаться на него из-за того, что зарплата в 4-5 раз выше той, которую они получили бы на родине, будучи занятыми той же работой (Shelia 2017).

По, по данным Всеобщей переписи населения 2014 г., среди эмигрирующих женщин возросло число профессиональных педагогов, и они представляют большинство. Профессиональная подготовка помогает им заграницей работать нянями, домработницами, сиделками у больных и престарелых лиц, т.е. заниматься характерной для сферы вторичного рынка «социально непрестижной» низкоквалифицированной работой, которой чурается местное население, тем более с высшим образованием (Shelia 2017).

После распада СССР векторы женской миграции из Грузии были направлены, кроме России, в сторону Турции и Азербайджана. В более поздний период произошла географическая диверсификация указанных потоков, например, часть потока в Россию переориентировалась на страны ЕС и США. Основные причины такой трансформации и расширения географии женской миграции: существенное смягчение, либерализация въезда в страны ЕС для граждан Грузии, постепенный рост знания английского языка, рост образовательного уровня трудовых мигрантов (за период между переписями населения Грузии 2002 и 2014 г. доля лиц с высшим образованием возросла: среди женщин с 24,6 до $37,2 \%$, а среди мужчин с 25,7 до 32,7\%), а также ухудшение экономической ситуации в России, падение курса рубля по отношению к доллару США и евро.

Вместе с тем определенная «пострановая специализация» в географии женской миграции все-таки наблюдается: в Германию и США в основном эмигрируют молодые, а в Грецию и Россию - преимущественно представительницы более старших возрастных групп. Основная причина в первом случае - доступность эффективной образовательной системы, а во втором - возможность трудоустройства. Во втором случае значительную роль также играют ментальная близость и религиозный фактор (Tukhashvili 2014: 367-375).

Основная причина женской миграции, как и вообще миграции из Грузии, экономическая: не только отсутствие в Грузии достаточного количества рабочих мест, но и большой удельный вес рабочих мест с относительно низким размером оплаты, массово воспроизводящим так называемую «занятую бедноту». Уровень женской безработицы в 
Грузии не очень отстает от мужской (соответственно 11,2 и 13,9\% - 2018 г.), но средняя оплата женского труда более чем на $1 / 3$ ниже, чем мужского, что является сильной мотивацией к трудовой эмиграции. Склонность к эмиграции сильнее у представительниц тех профессий и отраслей, где оплата труда женщин наиболее существенно отстает от мужской. Например, среди трудовых мигрантов-женщин преобладают представительницы сферы образования (учителя), где средняя оплата труда женщин наиболее существенно (почти вдвое) отстает от средней оплаты мужского труда.

Каждый четвертый трудовой мигрант покидает Грузию не из-за безработицы, а с целью увеличения текущего дохода своей семьи. За счет более жесткой экономии заработанных средств доля в заработанных средствах, частота и средний размер денежных переводов у женщин несколько выше, чем у мужчин.

В последние годы роль миграционного стимулятора начало играть наличие и расширение грузинской диаспоры в странах пребывания мигрантов. По данным выборочного обследования, каждые 100 женщин-трудовых мигрантов склоняют к миграции еще до 130 знакомых женщин-соотечественниц, в то время как среди мужчин соответствующий коэффициент не превышает 1. Женщины более контактны и солидарны в общении. Например, интенсивность общения в церкви со знакомыми в эмиграции у грузинских женщин раз в пять выше, чем у мужчин.

В настоящее время за пределами Грузии находится не менее 200 тыс. трудовых мигрантов-женщин. При гипотетическом одновременном их возвращении домой уровень безработицы среди женщин на родине увеличился бы в 3 раза. Получается, что трудовая миграция не только вносит вклад в снижение напряженности на рынке труда в Грузии, но и обеспечивает рост доходов и благосостояния домашних хозяйств, благоприятствует снижению уровня бедности. С другой стороны, массовый исход женщин из Грузии прямо бьет по репродуктивному потенциалу страны, способствует снижению и без того низкого уровня рождаемости. Это подталкивает Грузию к «членству» в клубе демографически вымирающих стран. Можно сказать, что нынешние социально-экономические трудности страны в значительной степени преодолеваются за счет «проедания» будущего демографического благополучия.

\section{НОВЫЕ ТЕНДЕНЦИИ В МИГРАЦИОННЫХ ПОТОКАХ ПОСЛЕДНИХ ЛЕТ}

В последние годы появились признаки серьезных изменений в направлениях миграционных потоков из Грузии и в Грузию.

Текущий статистический учет уловил симптомы сокращения эмигрантского потока, эмигрантского потенциала в Грузии при одновременном сохранении общей численности грузинских эмигрантов за рубежом. Впервые после обретения независимости в 2013 и 2015 г. миграционное сальдо среди мужчин, будучи до этого отрицательным, стало нулевым, а в 2017 г. - положительным, т.е. число иммигрантов превысило число эмигрантов. Среди иммигрантов большинство - граждане Грузии, что свидетельствует о возрастании среди грузинских эмигрантов прошлых лет желания возвратиться домой. Сокращение масштабов и роста потока эмиграции связаны со стабилизацией и ростом 
экономики страны, с масштабными инвестициями и денежными транзакциями из-за рубежа, повышением в целом уровня жизни в стране. Можно предположить, что эмигрантский настрой среди этой части населения почти иссяк, изменились их миграционное поведение и соответствующие ожидания.

Вместе с тем продолжает увеличиваться средний срок пребывания эмигрантов за рубежом. Если в 2000 г. только 40\% эмигрантов проживали за границей более 5 лет, то к 2014 г. этот показатель вырос до 68,8\%. За тот же период доля лиц, проживающих за рубежом менее 5 лет, сократилась с 58,0 до 18,5\%. Все еще значительное превосходство в оплате труда в этих странах, по сравнению с Грузией, играет роль своеобразного «якоря», удерживающего значительную часть грузинских мигрантов на чужбине в течении долгого времени.

В то же время обнадеживающие сдвиги в направлении миграционных потоков наблюдаются пока только среди мужчин, среди женщин они не наблюдаются. Число эмигранток все еще больше числа иммигранток. Основная причина этого -более легкая приспособляемость женщин к новым условиям работы и быта на чужбине и относительно устойчивые режим и место работы. Тем не менее нельзя исключать, что в обозримом будущем (по нашим оценкам, уже через 3-5 лет) модель миграционного поведения женщин повторит модель поведения мужчин «образца середины 2010-х».

\section{СПЕЦИАЛЬНОЕ ОБСЛЕДОВАНИЕ СТУДЕНЧЕСКОЙ ПРЕДРАСПОЛОЖЕННОСТИ К МИГРАЦИИ. МИГРАЦИОННЫЙ ПОТЕНЦИАЛ СТУДЕНТОВ (ОБЩИЕ РЕЗУЛЬТАТЫ ОБСЛЕДОВАНИЯ)}

На фоне того, что с возрастом эмиграционный настрой населения Грузии снижается, у молодежи, особенно студентов, наблюдается противоположная картина. У них наблюдается выраженная ориентация на выезд за границу. Это обстоятельство во многом предопределяет интерес к их (с высокой долей вероятности-потенциальных мигрантов) отношению, мотивам и факторам выезда за границу.

Основная причина молодежной мотивации к эмиграции - не только (и не столько!) желание познать мир. Решающий вклад в эту мотивацию вносит низкая заработная плата и в целом неудовлетворительный уровень благосостояния, а также неясная перспектива трудоустройства и высокий уровень безработицы среди молодежи. По данным за 2018 г., уровень безработицы среди молодежи в возрасте до 25 лет составляет 29,9\%, тогда как среди остального населения-почтив 2,4 раза меньше (12,7\%); среди молодежи в возрасте до 25 лет трудоустроена лишь треть и лишь каждый шестой является наемным работником (рисунок 4). Молодежь в возрасте 15-25 лет составляет 14,4\% среди всего населения старше 15 лет, среди экономически активного населения - 8,7\%, а среди экономически неактивного населения - 22,8\%. На каждые 100 занятых по найму на лиц старше 25 лет приходится лишь 25 безработных, в то время как соответствующий показатель среди юношей в возрасте до 25 лет почти в 3 раза выше - 73 на 100. 


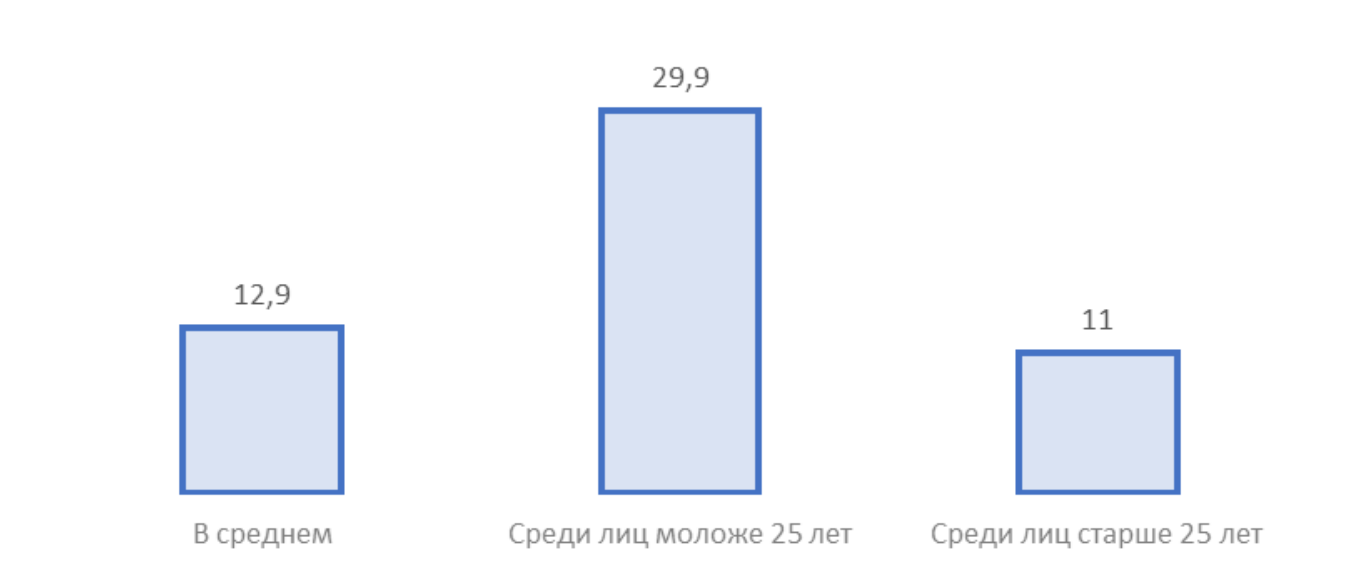

Рисунок 4. Уровень безработицы в Грузии в 2018 г., \%

Источник: данные Грузстата. URL: www.geostat.ge (дата обращчения: 28.05.2019).

В 2017 г. Институт демографии и социологии Государственного университета Ильи опросил с учетом репрезентативности 1250 студентов вузов столицы и некоторых других городов Грузии (примерно 1\% от общего числа студентов в стране). Студентам задавали вопросы следующего содержания: планирует ли он выехать за гранииу в течение ближайших трех лет и куда; какова мотивация выезда; намерен ли вернуться и когда; размер желаемой зарплаты в Грузии и за рубежсом; готовность к эмиграции (изучение языка, накопление денег, выбор предполагаемой страны и др.). На основе всего этого был оценен эмиграционный потенциал студентов. Полученные данные внесли больше ясности в миграционную мотивацию населения с учетом соответствующих данных переписей населения и некоторых других исследований.

В результате социологического опроса выяснилось, что 42,7\% опрошенных студентов хотели бы выехать за границу. Сегодня среди студентов контингент потенциальных мигрантов лишь в 1,3 раза отстает от числа студентов, которые хотят остаться в своей стране, что создает серьезную угрозу социально-экономическому и демографическому развитию малочисленной Грузии.

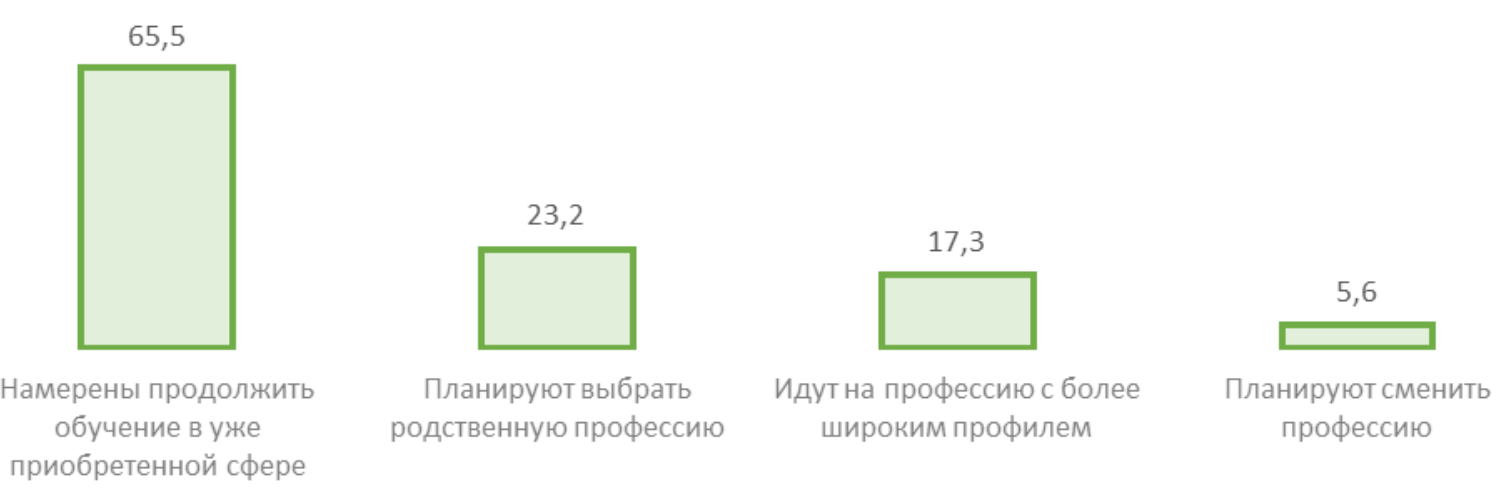

\section{Рисунок 5. Планы дальнейшего обучения студентов в случае эмиграции, \%}

Источник: (Институт демографии... 2017). 
Причина к столь высокой степени предрасположенности к эмиграции кроется не в ошибочном выборе профессии. 65,5\% студентов намерены продолжить обучение в сфере уже приобретенной профессии. 23,2\% планируют выбрать родственную профессию, 17,3\% предпочитают профессии с более широким профилем и лишь 5,6\% планируют сменить профессию (рисунок 5).

Из того, что в Грузии более 100 тыс. студентов, следует, что примерно 43-45 тыс. из них рассчитывают в ближайшие годы покинуть родину для продолжения учебы или работы. Следует, однако, учесть, что желание уехать за границу и действия, предполагаемые для этого, часто по времени и масштабам не совпадают. По тому, как студенты готовятся к эмиграции (изучение иностранного языка, ознакомление с законодательством соответствующей страны и др.) можно судить о потенциале миграции, который, по нашим расчетам, в Грузии находится в пределах 16-20\% от общей численности студентов.

Имеются два основных мотива для выезда за рубеж: получение или повышение уровня образования и трудовая деятельность. На долю мотивированной таким образом молодежи приходится более 9/10 желающих выехать за рубеж. Среди желающих выехать заграницу 3/5 намереваются оставить Грузию в ближайшие 3 года, а $2 / 5$ - попозже. Мотивация к выезду из страны у девушек несколько выше, чем у юношей (соответственно 59,6 и 52,0\%, в среднем для обоих полов - 55,6\%). 34,2\% опрошенных считают, что у получившего образование заграницей больше шансов найти работу в Грузии; каждый восьмой $(12,1 \%)$ считает, что зарубежное образование может открыть им «путевку в жизнь» и дать возможность работы за пределами собственной страны. К тому же среди юношей преобладает мотивация трудовой занятости, а среди девушек - учебы.

Большинство молодых людей - потенциальных мигрантов $(59,0 \%)$ планируют совмещать учебу с работой, при то что очень велики гендерные различия. Эмигрантские настроения большинства девушек ориентированы на учебу $(63,6 \%)$, что в 1,7 раза превышает соответствующий показатель для юношей $(37,4 \%)$.

Намеревается вернуться на родину почти половина $(49,8 \%)$ желающих выехать за границу с целью получения образования. Из желающих учиться за рубежом 47,0\% намереваются принять решение (остаться в эмиграции или вернуться на родину) лишь по окончании учебы.

Из всего контингента желающих выехать заграницу каждый четвертый студент примет окончательное решение возвращаться на родину или нет только после завершения учебы за рубежом. В ходе опроса лишь чуть более $3 \%$ опрошенных заявили о твердом решении не возвращаться обратно. В абсолютных цифрах это означает, что минимум почти 350-400 молодых людей с самого начала четко решили после получения образования за рубежом стать невозвращенцами. И с демографической, и с экономической точки зрения это однозначно негативный предвестник: окончательный отъезд молодых людей их Грузии не только не будет способствовать улучшению воспроизводства населения, но и ударит по экономическим интересам страны, теряющей человеческий капитал с высоким образовательным уровнем. 
После окончания университета в Грузии 12,3\% студентов намерены продолжить учебу в магистратуре или докторантуре, $26,8 \%$ планируют начать работать, а $10,1 \%$ еще не определились. Кроме того, почти половина из общего числа студентов $(46,6 \%)$ намерены сразу после окончания вуза трудоустроиться. В целом из желающих уехать за границу почти $2 / 3(65,5 \%)$ хотят продолжить учебу по выбранной на родине специальности, каждый четвертый $(23,2 \%)$ - по смежной специальности, каждый шестой $(17,3 \%)$ - по специальности более широкого профиля, лишь каждый восемнадцатый думает поменять специальность.

Из каждых 6 студентов 5 хотят продолжить обучение в магистратуре или докторантуре, в то время как каждый 10-й студент планирует учиться за рубежом на степень бакалавра. Большинство из этих молодых людей считают, что получение степени бакалавра в их собственной стране является необходимым, но недостаточным условием для построения и развития карьеры в будущем.

Как показал опрос, в структуре образовательных предпочтений грузинских студентов преобладают экономические и бизнес-административные профессии $(45,6 \%)$,причем, девушки (46,7\%) выбирают эти специальности чаще, чем юноши $(44,5 \%)$. Гуманитарные науки в равной степени выбираются и юношами, и девушками, в то время как в других областях, особенно в области инженерии, число юношей превышает число девушек. По сельскохозяйственным специальностям в основном обучаются юноши.

География выезда из страны имеет несколько векторов, студенты готовы выехать в Германию (37,2\%), США (16,8\%), Великобританию $(11,4 \%)$, Италию $(5,4 \%)$, Францию и Россию (по 3,4\%) - см. рисунок 6.

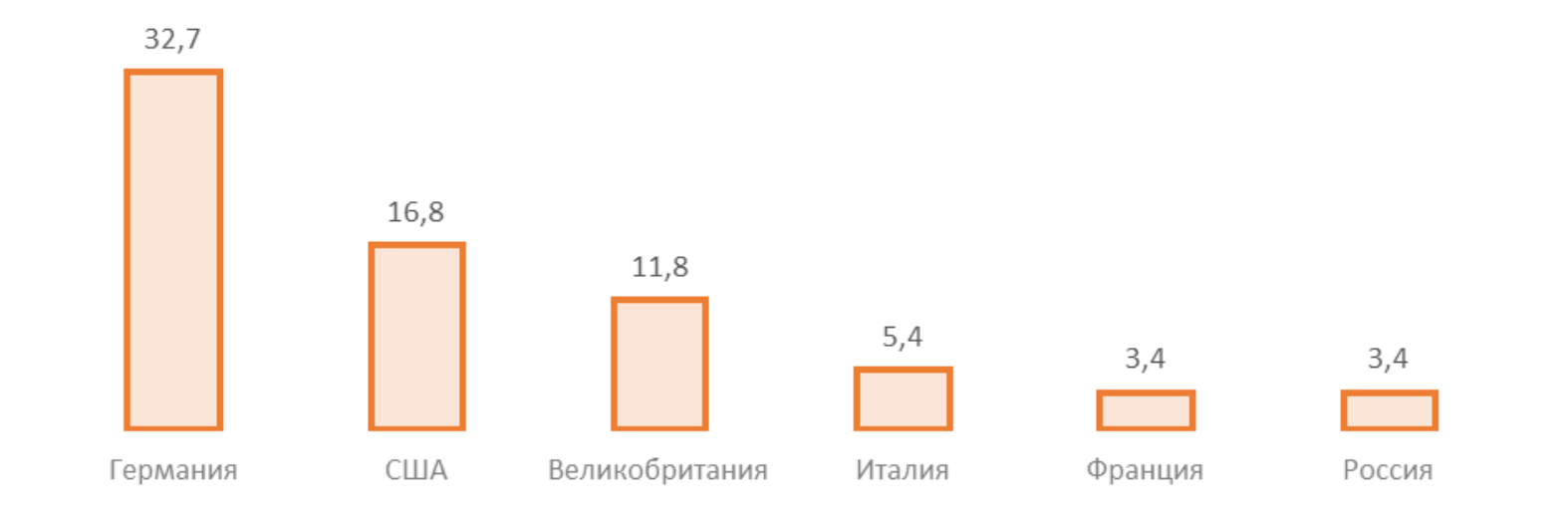

Рисунок 6. География потенциальной эмиграции студентов, \%

Источник: (Институт демографии... 2017)

Примерно 3/5 из знающих английский намерены уехать в те страны, где этот язык является официальным (США, Великобритания). Для остальных знание английского языка - это способ улучшить свое образование или найти работу в других странах. В связи с этим особенно примечательна Германия: число желающих выехать в эту страну в 5,6 раза больше числа владеющих немецким языком (соответственно 37,2 и 6,6\%).

Противоположная картина наблюдается на «российском направлении». Число желающих выехать в Россию в 6,6 раза меньше числа говорящих на русском языке. Среди 
крупных стран, куда хотят выехать студенты, Россия - единственная, желающих выехать в которую меньше, чем знающих язык принимающей страны. Среди владеющих иностранным языком студентов коэффициент знания языка составляет 1,18 , что отстает от среднего европейского показателя почти в 1,4 раза (Европейский Союз - 1,6 и более). Примечательно, что в 2017 г. 60\% студентов Европейского Союза знали 2 языка и более.

Студенты осознают, что для достижения успеха за рубежом, будь то учеба или трудовая деятельность, необходимо знание языка принимающей страны и/или английского языка. Именно поэтому $43 \%$ решивших поехать учиться за границу изучают иностранный язык. Этот показатель в 2,5 раза превышает число студентов, не владеющих никакими иностранными языками $(17,7 \%)$.

Масштабы трудовой миграции в Грузии оказывают серьезное влияние не только на демографическую структуру населения страны, но и на размер денежных транзакций, проведенных трудовыми мигрантами из Грузии на родину. По самым осторожным оценкам, 12-15\% денежных переводов, осуществляемых из-за рубежа в Грузию, приходится на возрастную группу моложе 25 лет. Иными словами, только в 2011-2018 гг. молодежь в возрасте до 25 лет осуществляла денежные операции из-за рубежа на сумму не менее 1,31,6 млрд долларов США. Этот показатель в 2,4-3,0 раза превышает размер бюджетных ассигнований Грузии на высшее образование за тот же период и соответствует примерно $27.3 \%$ среднегодового дохода всего населения Грузии. Размер транзакций достаточно солидный - с 2000 г. он увеличился почти в 25 раз (рисунок 7), хотя в целом, на фоне потерь, которые вызваны массовым оттоком энергичной, амбициозной и компетентной молодежи из страны, эффективность, экономическая и социальная рентабельность упомянутых переводов в значительной степени обесценивается.

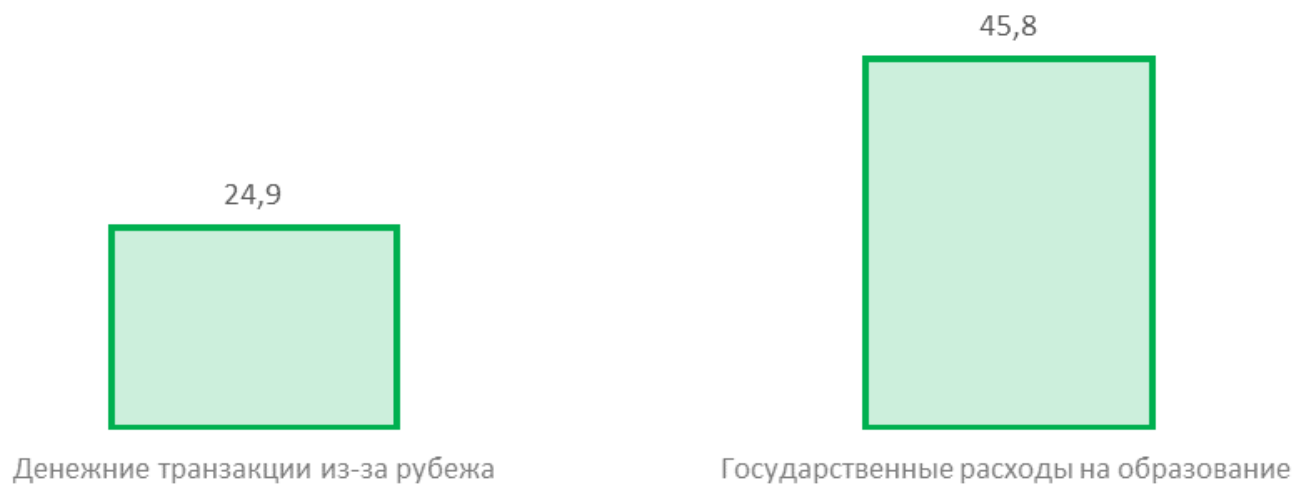

\section{Рисунок 7. Рост денежных транзакции из-за рубежа и государственных расходов на образование в Грузии за 2000-2018 г., раз (2000 г. = 1)}

Источник: Данные Грузстата. URL: www.geostat.ge (дата обращчения: 31.05.2019).

\section{ЗАКЛЮЧЕНИЕ}

Экономическая стабилизация и рост благосостояния населения, достигнутые в Грузии за последние годы, позитивно влияют на трансформацию сальдо внешней миграции, вследствие чего уменьшается число эмигрантов и начинают проявляться определенные 
признаки роста возвратной иммиграции. Более интенсивному процессу возвращения мигрантов и сведению на нет эмиграции из Грузии препятствует медленный рост экономики, который не поспевает за непрерывным ростом потребностей населения.

В настоящее время Грузия не сталкивается с масштабами эмиграции 1990-х - начала 2000-х годов. Тем не менее высокий уровень образования среди желающих эмигрировать, существенный рост доли лиц с высшим академическим образованием и квалификацией в эмигрантском контингенте усиливают проблему «утечки мозгов». Растущая доля людей с высшим образованием и квалификацией среди выбывших (или желающих выехать) из страны означает, что вложенная в каждого мигранта стоимость образования и квалификации-прогрессивно растущая величина. Иначе говоря, затраты, вложенные в стране, в том числе государством, для достижения соответствующей кондиции уехавшего в эмиграцию врача, программиста, инженера и др., становятся все больше, что тяжелым бременем ложится на экономику и бюджет страны. То есть для Грузии экономический эффект от трудовой эмиграции ее граждан, выраженный в денежных переводах из-за рубежа, с учетом затрат государства и семьи на образование и подготовку по определенной специальности будущего «потенциального мигранта», постепенно улетучивается, сходит на нет. Но это не снижает довольно высокую мотивацию выезда заграницу студентов высших учебных заведений, поскольку, по их оценкам, полученное за рубежом вознаграждение по сравнению с тем, которое они могут получить на родине, будет приблизительно в 2,5 раза выше.

Можно предположить, что определенная часть студентов после окончания учебы примет решение остаться за рубежом. С демографической точки зрения, это означает потерю заметной части молодежи, что ухудшит и без того низкие показатели воспроизводства населения. С экономической же точки зрения, страна потеряет человеческий капитал с высоким образовательным уровнем.

Соответственно, в ближайшие годы государственная стратегия по отношению к трудовой миграции должна быть направлена на постепенное уменьшение потерь Грузии из-за указанных обстоятельств и на максимизацию того социально-экономического эффекта, который могут предоставить стране находящиеся заграницей трудовые мигранты путем транзакций не только своих финансовых ресурсов, но и знаний, навыков и опыта управления бизнесом, деятельности в сфере государственного управления и политики. Должны быть созданы и задействованы рычаги, с помощью которых появится возможность не механически обуздать эмиграцию (это невозможно с юридической точки зрения и негуманно с точки зрения прав и свобод личности), а чисто экономическими методами стимулировать возвратную иммиграцию, в том числе за счет налоговой амнистии для капиталов, выведенных из Грузии в первые десятилетия после обретения независимости, и создания налоговых льгот для иммигрантов, покинувших Грузию ранее (Archvadze 2017: 79-95).

В последние годы в формировании миграционного сальдо Грузии все более возрастающую роль начинает играть миграционная активность граждан других государств. Среди неграждан Грузии по количеству въездов в Грузию и выездов из Грузии стабильно имеется положительное сальдо. Оно за последние 5 лет почти удвоилось и уже почти на 
9/10 покрывает отрицательное миграционное сальдо для граждан Грузии. Следует отметить, что в то время, как отрицательное миграционное сальдо по гражданам Грузии в основном формируется за счет оттока коренного населения в европейские страны и США, положительное сальдо по негражданам Грузии складывается преимущественно за счет притока из восточных стран.

Хотя среди граждан Грузии миграционное сальдо для обоих полов отрицательное, тем не менее в последние годы отмечается существенное опережение роста отрицательного сальдо среди женщин по сравнению с соответствующим показателем среди мужчин. В настоящее время в общей численности эмигрантов из Грузии доля женщин составляет $54,6 \%$ (в начале XXI столетия- 43\%).

Совершенно противоположная картина наблюдается по миграционному сальдо среди неграждан Грузии. При общем положительном миграционном сальдо положительное сальдо для мужчин существенно опережает такое же сальдо для женщин.

В целом из-за вышеуказанной диспропорции миграционного сальдо среди женщин и мужчин разность между мужским и женским населением Грузии ежегодно сокращается на 6-7 тыс. человек при пока сохраняемом численном перевесе женщин (соответственно $52,0$ и $48,0 \%)$.

Новый импульс динамике миграционного процесса придало введение с апреля 2017 г. безвизового режима посещения стран Европейского Союза. За последние неполных два года этой возможностью воспользовались почти 400 тыс. (390175) граждан Грузии, успевших посетить страны шенгенской зоны 673916 раза. В соответствии с нормативными актами, срок безвизового пребывания на территории ЕС составляет в общей сложности 90 дней в году, но, согласно информации, полученной от Департамента охраны границы Грузии, немалому числу эмигрантов (более 10 тыс. граждан Грузии) уже «удалось» нарушить этот срок. Немало лиц, воспользовавшихся возможностью безвизового посещения соответствующих стран, пренебрегли ограничением непрерывного 90-дневного пребывания в принимающих странах или же пополнили ряды нелегалов ${ }^{8}$.

Причины нелегальной миграции и безосновательного прошения предоставления убежища весьма тривиальны - они напрямую связаны с высоким жизненным стандартом и степенью социальной защиты в странах ЕС-28. Из общей численности лиц, впервые просивших предоставления убежища в странах ЕС-28 за 2018 г., 3,1\% (17980 человек) были гражданами Грузии. Хотя это один из низких показателей среди стран, чьи граждане требуют предоставления статуса беженца и возможности легального проживания в ЕС-28 (Aptsiauri, Sulaberidze 2019: 494-500), с учетом реальной социально-экономической и политической ситуации в Грузии, условий прав и свобод граждан, абсолютное большинство поданных гражданами Грузии прошений были отклонены.

В последнее время появляются признаки попыток придать трудовой миграции из Грузии более организованную форму. Например, в рамках Польского партнерского договора (Грузия подписала такое соглашение с ЕС в 2009 г.) гражданам Грузии было

\footnotetext{
${ }^{8}$ URL: https://www.easo.europa.eu/asylum-trends-overview-2018 (дата обращения: 13.02.2019). 
выдано 398 разрешений на трудоустройство в Польше. Этот вид разрешения позволяет им работать на территории Польши легально в течение 6 месяцев, начиная со следующих 12 месяцев. Канцлер Германии Ангела Меркель во время своего визита в Тбилиси в августе 2018 г. также заявила о возможности организованной и контролируемой трудовой миграции из Грузии в Германию. Аналогичные переговоры ведутся и с Израилем. Тем не менее слишком большое число трудовых мигрантов и их разброс по всему миру приводят к неутешительному выводу о том, что большинство трудовых мигрантов их Грузии в течение ближайших нескольких лет все равно будут вынуждены искать работу и обосновываться за рубежом за счет собственных усилий, на свой страх и риск.

Тем не менее в целом перспективы миграции на ближайшие десятилетия нельзя считать пессимистичными. Как показывают исследования, оценки независимых экспертов, а также прогнозы ООН, миграционный обмен Грузии с другими странами характеризуется постепенным сокращением отрицательного сальдо. В общем потоке прогнозов есть и более оптимистические сценарии. Если прогнозы ООН и других специализированных институтов декларируют только уменьшение отрицательного миграционного сальдо, отдельные демографы (Sulaberidze et.al 2016: 6-7) дают боле оптимистичный прогноз, предполагая, что уже к 2025-2030 гг. отрицательное миграционное сальдо сменится положительным.

\section{ЛИТЕРАТУРА}

Арчвадзе И. (2013). Влияние трудовой миграции на индикаторы характеризующих состояние рынка труда (на примере Грузии). Миграция, 6, 104-118 (на грузинском языке).

Арчвадзе И. (2017). Природа и масштабы репатриации денежных средств трудовыми мигрантами (На примере Грузии и ее соседей). Мигращия, 8, 79-96 (на грузинском языке).

Вишневский А. Г. (2015). Время демографических перемен. М.: Издательский дом НИУ ВШЭ.

Денисенко М.Б., Чудиновских О.С. (2018). Долгосрочная миграция между странами СНГ. В М.Б. Денисенко, Р.В. Дмитриева, В.В. Елизаров (Ред.). Демографическое развитие постсоветского пространства(с. 182-205). М.: Экономический факультет МГУ им. M.В. Ломоносова. URL: https://www.econ.msu.ru /sys/raw.php? o=44887\&p=attachment

Институт демографии и социологии Государственного Университета Ильи (2017).

Материалы социологического исследования. «Студенческая предрасположенность к миграции».

Сулаберидзе А. (2017). Методологические проблемы статистического учета миграции и его результаты в Грузии. Миграция, 8, 70-77 (на грузинском языке).

Цуладзе Г., Сулаберидзе А. (2016). Демографические особенности регионов Грузии. Тбилиси (на грузинском языке).

Шелия М. (2017). Женская эмиграция из Грузии. Мигращия, 8, 114-133 (на грузинском языке).

Aptsiauri G., Sulaberidze A. (2019, June), Challenges of citizens mobility between Georgia and European Union based on free visa liberation policy. In R. Abesadze (Ed.), Report of 
International conference: Proceedings of Materials of International Scientific Conference "current problems of formation of "Green economy". (pp. 494-500). Tbilisi. Retrieved from http://www.pgie.tsu.ge/contentimage/konferenciebi/conf.kreb.2019.pdf

Sulaberidze A. (2008). Distorted Migration Temps: Cui Bono? The Caucasus and Globalization. Journal of Social, Political and Economic Studies, 2 (1), 82. Retrieved from http://www.cac.org/c-g-online/2008/journal_eng/c-g-1/k-g-E-01-2008.pdf

Sulaberidze A., Tsuladze G., Sulaberidze V., Gomelauri N. (2016). Census Statistic Problems in Demographic Cases in Georgia. In A. Sulaberidze (Ed.), Collection of works: Problems of Demography and Sociology (pp. 6-17). Tbilisi.

Tsuladze G., Maglaperodze N., Vadachkoria A. (2002). Demographic overview of Georgia (1960-2000). UNFPA. Tbilisi. Retrieved from https://www.tsu.ge/data/file_db/ faculty_social_political/DEMOGRAPHIC\%20OVERVIEW\%200F\%20GEORGIA.pdf

Tsuladze G., Maglaperidze N., Vadachkoria A. (2005).Demographic yearbook of Georgia 2004. UNFPA.

Tsuladze G. (2016). Demographic yearbook of Georgia 2015.

Tukhashvili A. (2014). Potential Educational Emigration of Georgian Students for Study Purposes. In H. Arslan, G. Raţă,E. Kocayörük, M. Ali İçbay (Eds.), Multidisciplinary Perspectives on Education (pp. 367-374). Cambridge Scholars Publishing. Retrieved from https://www.kriso.ee/multidisciplinary-perspectives-education-db-97814438617242e.html

Tukhashvili M. (2018). Retrospective Comprehension of Post-Soviet Georgia's Population Migration. Bulletin of the Georgian National Academy of Science, 12(1), 175-181. Retrieved from http://science.org.ge/bnas/t12-n1/28_Tukhashvili.pdf 


\title{
THE MAIN FACTORS OF MIGRATION AND THE STRUCTURE OF MIGRANTS IN POST-COMMUNIST GEORGIA
}

\author{
AVTANDIL SULABERIDZE, JOSEPH ARCHVADZE, VLADIMIR SULABERIDZE
}

\begin{abstract}
The steady growth of emigration during the Post-Soviet period (1992-2014) under conditions of zero natural population increase had a profound effect on the social-demographic and economic development of Georgia?. Since 1992, the population size has decreased by almost 1/3, coming to 3.7 million by 2018.

The emigration was basically a process involving three factors. First came ethnic migration, when, after the collapse of the Soviet Union, members of tens of thousands of other nationalities living in Georgia returned to their historical homeland. As a result, the share of Georgians in the total population increased from $69.7 \%$ to $86.8 \%$ in 1989-2017. The second factor was the emigration of a large mass of refugees from lost territories (Abkhazia and South Ossetia), and the third factor was a social-economic collapse.

The high level of emigration caused the deformation of the population's age-sex structure. The median age of the population of Georgia increased by nearly 8 years, which is the highest figure among the Post-Soviet countries.

From amongst the many aspects of migration, there are two that deserve special attention: the rise of the emigration of women (although men still exceed women among the emigrants) and of students (youth). Lately, the educational qualification of emigrants has been systematically rising, making the issue of "the brain drain" from the country ever more critical.

A strong motivation to emigrate is found among young students, nearly $48 \%$ of whom intend to go abroad in order to study and work within the next five years.
\end{abstract}

Keywords: migration, motivation, labour migrants, illegal migration.

Avtandil Sulaberidze (sulaberidzeavtandil@gmail.com), Institute of DeMOGRAPHY AND Sociology ILIA STATE UNIVERSITY, GEORGIA.

JoSEPh ARChVAdZE (daswreba@yahoo.com), InSTITUTE of DEMOGRAPHY AND SOCIOlOgy Ilia STATE UNIVERSITY, GEORGIA.

Vladimir Sulaberidze (lado.posta@gmail.com), InSTituTe of DEMOGRAPHY AND Sociology Ilia STATE UNIVERSITY, GEORGIA.

DATE RECEIVED: AUGUST2019.

\section{REFERENCES}

Aptsiauri G., Sulaberidze A. (2019, June), Challenges of citizens mobility between Georgia and European Union based on free visa liberation policy. In R. Abesadze (Ed.), Report of International conference: Proceedings of Materials of International Scientific Conference "current problems of formation of "Green economy", (pp. 494-500). Tbilisi. Retrieved from http://www.pgie.tsu.ge/contentimage/konferenciebi/conf.kreb.2019.pdf

Archvadze J. (2013). The effect of labor migration on the characteristic indicator of labor market situation (The case of Georgia). Migration, 6, 104-118 (In Georgian).

Archvadze J. (2017). The Nature and Scale of Repatriation Money of Migrant Workers (On the example of Georgia and its land neighbors). Migration,8, 79-96 (In Georgian). 
Denisenko M.B., CHudinovskikh O.S. (2018). Dolgosrochnaya migratsiya mezhdu stranami SNG [Long-term migration between the CIS countries]. In M.B. Denisenko, R.V.

Dmitriyeva, V.V. Elizarov (Eds.), Demograficheskoye razvitiye post-sovetskogo proctranstva (pp. 182-205) [Demographic development of the post-Soviet space]. Moscow:

Ekonomicheskiy fakultet MGU im. M.V. Lomonosova Retrieved from https://www.econ.msu.ru /sys/raw.php? o=44887\& p=attachment (In Russ.).

Institut demografii I sotsiologii Gosudarstvennogo Universiteta Il'i [Institute of Demography and Sociology Ilia State University] (2017). Materialys ot siologicheskogo issledovaniya.

Studencheskaya predraspolozhennost' k migratsii» [Materials of the sociological research. "Migratory disposition of students"] (In Georgian).

Shelia M. (2017). Women's Emigration from Georgia. Migration, 8, 114-133 (In Georgian).

Sulaberidze A. (2008). Distorted Migration Temps: Cui Bono? The Caucasus and Globalization. Journal of Social, Political and Economic Studies, 2(1), 82. Retrieved from http://www.cac.org/c-g-online/2008/journal_eng/c-g-1/k-g-E-01-2008.pdf

Sulaberidze A. (2017). Methodological Problems of Statistical Accounting of Migration and its Results in Georgia. Migration, 8, 70-77 (In Georgian).

Sulaberidze A., Tsuladze G., Sulaberidze V., Gomelauri N. (2016). Census Statistic Problems in Demographic Cases in Georgia. In A. Sulaberidze (Ed.), Collection of works: Problems of Demography and Sociology (pp. 6-17). Tbilisi.

Tsuladze G. (2016). Demographic yearbook of Georgia 2015 (In English, in French, and in Georgian).

Tsuladze G., Maglaperidze N., Vadachkoria A. (2005). Demographic yearbook of Georgia 2004. UNFPA (In English, in French, and in Georgian).

Tsuladze G., Maglaperodze N., Vadachkoria A. (2002). Demographic overview of Georgia (1960-2000). UNFPA. Tbilisi. Retrieved from https://www.tsu.ge/data/file_db/ faculty_social_political/DEMOGRAPHIC\%20OVERVIEW\%20OF\%20GEORGIA.pdf

Tsuladze G., Sulaberidze A. (2016). Demographic peculiarities of Georgian regions. Tbilisi (In Georgian).

Tukhashvili A. (2014). Potential Educational Emigration of Georgian Students for Study Purposes. In H. Arslan, G. Raţă,E. Kocayörük, M. Ali İçbay (Eds.), Multidisciplinary Perspectives on Education (pp. 367-374). Cambridge Scholars Publishing. Retrieved from https://www.kriso.ee/multidisciplinary-perspectives-education-db-97814438617242e.html

Tukhashvili M. (2018). Retrospective Comprehension of Post-Soviet Georgia's Population Migration. Bulletin of the Georgian National Academy of Science, 12 (1), 175-181. Retrieved from http://science.org.ge/bnas/t12-n1/28_Tukhashvili.pdf

Vishnevsky A.G. (2015). Vremya demograficheskikh peremen [The Time of demographic changes]. Moscow: Izdatel'skiy dom NIU VSH·E (In Russ.). 